\title{
School environment and individual factors influence oral health related quality of life in Brazilian children
}

\section{Renan Vaz MACHRY(a) Jessica Klöckner KNORST ${ }^{(b)}$ Fernanda TOMAZONI(b) Thiago Machado ARDENGHI(b)}

(a) Universidade Federal de Santa Maria UFSM, Faculty of Dentistry, Department of Restorative Dentistry, Santa Maria, RS, Brazil.

(b) Universidade Federal de Santa Maria UFSM, Faculty of Dentistry, Department of Stomatology, Santa Maria, RS, Brazil.

Declaration of Interests: The authors certify that they have no commercial or associative interest that represents a conflict of interest in connection with the manuscript.

\section{Corresponding Author:}

Fernanda Tomazoni

E-mail: fei_tomazoni@hotmail.com

https://doi.org/10.1590/1807-3107bor-2018.vol32.0063

Submitted: January 25, 2018

Accepted for publication: May 14, 2018

Last revision: May 25, 2018

\begin{abstract}
The aim of this study was to verify the influence of school environment and individual factors on oral health related quality of life (OHRQoL) in a representative sample of Brazilian schoolchildren. A cross-sectional study was conducted with 1,134 12-year-old schoolchildren from Santa Maria, Southern Brazil. Clinical variables were obtained from examinations carried out by calibrated individuals. In addition, parents/guardians answered a semi-structured questionnaire about sociodemographic characteristics. Contextual variables were obtained from the city's official database, including the mean income of the neighborhood in which the school was located and the Basic School's Development Index (IDEB) of the school. The Brazilian version of the Child Perception Questionnaire (CPQ11-14) was used to access OHRQoL. Data analysis was conducted using multilevel Poisson regression. Children studying in schools with a higher classification on the IDEB presented a lower CPQ11-14 mean score (rate ratio 0.80, 95\%CI 0.74-0.88) than those studying in schools with a lower IDEB. Regarding individual variables, children with carious cavities, malocclusion, and gingival bleeding presented higher CPQ11-14 mean values than their counterparts. The same was observed in children from families with low socioeconomic status. School environment, and individual clinical and socioeconomic factors were associated with schoolchildren's OHRQoL.
\end{abstract}

Keywords: Child; Quality of Life; Oral Health.

\section{Introduction}

Decision making in dentistry should not be based only on the assessment of oral health, considering the presence or absence of disease. Contemporary concepts of oral health state that assessments should cover physiological, social, and psychological aspects of the individual, which are essential factors for patients' quality of life. ${ }^{1}$ Therefore, the oral health related quality of life (OHRQoL) has been widely advocated as an adjunct to clinical parameters in planning public health policies, prioritization of services, and evaluating outcomes of oral health strategies. ${ }^{2}$

Previous studies that evaluated OHRQoL in infant populations have demonstrated a negative influence of clinical conditions, such as presence of dental caries, malocclusion, and gingivitis on well-being during childhood and adolescence. ${ }^{3,4,5,6}$ The same has been observed when considering 
socioeconomic and psychosocial factors, where individuals exposed to unfavorable characteristics such as low family income, low parental schooling and family problems reported a worse OHRQoL than individuals without those characteristics. ${ }^{3,4,7}$

Besides the influence of individual factors, the literature has also demonstrated that the exposure to contextual and environmental characteristics may have an influence on self-perception of health and its impact on people's lifes. ${ }^{8,9}$ Thus, when assessing the relationship between different health outcomes and individual determinants, it is important to consider the source of variability from different hierarchical levels. ${ }^{10}$ It has been shown that aspects like family environment influence children's and adolescents' self-perception of oral health and OHRQoL..$^{11,12}$ As important as the family structure, understanding the influence of school environment on oral health and OHRQoL deserves special attention, once school is where children have their experiences as a group, and develop their learning and intellectual formation.

Evidence about the role of determinants related to the school context in OHRQoL are scarce. Therefore, this study aimed to assess the impact of school environment and individual factors on the OHRQoL of 12-year-old schoolchildren from Southern Brazil. The hypothesis of this study was that children attending schools in low-income neighborhoods and with low classification in the Basic school's Development Index (IDEB) are more likely to report poor OHRQoL.

\section{Methodology}

\section{Ethical aspects}

The study protocol was reviewed and approved by the Ethics Committee in Research of the Federal University of Santa Maria. All the subjects consented to participate, and their parents or guardians signed a written informed consent form.

\section{Sample}

This cross-sectional study included 1,134 12-yearold schoolchildren from public schools in Santa Maria, a southern city in Brazil. The city has an estimated population of 261,031 inhabitants, including 3,817 12 -year-old individuals $(85 \%$ enrolled in public schools). Sample size calculation was performed considering the following parameters: $5 \%$ standard error, $80 \%$ power, $95 \%$ confidence level, odds ratio of 2.2 in the exposed group (more than 4 decayed teeth $)^{13}$ and the ratio exposed/unexposed of 1:1. With the addition of an extra 30\% due to nonresponses, the minimum sample size was set at 1,082 subjects.

Individuals were selected using a two-stage cluster-sampling. The primary sampling unit were all public schools in the city: a total of 20 out of 39 schools were randomly selected. As the schools had different sizes, an equal probability selection method - probability proportional size - was used. The second sampling unit included all 12-years-old students attending each selected school. Students who were not intellectually capable of responding the questionnaire or had any other physical incapacity were excluded from the sample.

\section{Data collection}

Data collection was carried out from March to October 2012, including clinical examinations and questionnaires. Four previously trained and calibrated examiners conducted the examinations at the schools following the standard international criteria from the World Health Organization for oral health surveys: ${ }^{14}$ examinations were done in a room with natural light, using dental mirrors and periodontal probes (CPI; "ball point"). Three interviewers also participated in the data collection.

The calibration process lasted 36 hours. It included first an 8-hour session with theoretical explanation of the diagnostic criteria used. After that, 10 children were clinically evaluated in order to assess and discuss different levels of the oral health outcomes. Lastly, 20 children were examined twice by the same examiner, with an interval of 2 weeks between each examination. The same dental examiner conducted the complete process.

\section{Individual variables}

Dental caries was assessed according to the WHO criteria (DMFT index) ${ }^{15}$ and dichotomized considering the prevalence of untreated dental caries into "present" 
(corresponding to a non-zero D component in the DMFT index) or "absent" (D component of the DMFT index equal to zero). Malocclusion was assessed according to the DAI criteria ${ }^{16}$ and classified as "presence of malocclusion" (moderate, severe, or disabling) or "normal occlusion". Gingival bleeding was assessed according to the CPI criteria ${ }^{15}$ and dichotomized in "extensive levels of gingival bleeding" ( $\geq 15 \%$ of sites) and "low levels or absence of gingival bleeding" $(<15 \%$ of sites $){ }^{17}$

Socioeconomic and demographic characteristics were collected using a self-administered questionnaire that was answered by the parents or guardians. The questionnaire evaluated information regarding gender, race, parents' educational level, household income, religiosity and visits to dentist. Race was recorded according to the criteria of the Brazilian Institute of Geography and Statistics (white, black, mixed, or other) and then dichotomized into "white" or "non-white". ${ }^{18,19}$ Household income was measured in terms of Brazilian minimum wage (BMW), which was approximately \$450 USD at the time of the survey, and categorized in income tertiles: wealthiest $\left(3^{\text {rd }}\right.$ tertile), intermediary $\left(2^{\text {nd }}\right.$ tertile), and poorest ( $1^{\text {st }}$ tertile). Mother's educational level was dichotomized as those who completed the 8 years of primary school and those with less than 8 years of school. Regarding religiosity, parents answered if they identified themselves with the phrase: "I make a big effort to live my religion in all aspects of life". The responses were categorized into "yes" or "no". Individuals were also classified as those who had visited the dentist in the previous 6 months and those who did not. The viability of the socioeconomic questionnaire was previously assessed in a sample of 20 parents during the calibration process, which data was not included in the final sample.

Children answered the Brazilian short version of the Child Perceptions Questionnaire (CPQ11-14) to provide information about $\mathrm{OHRQoL},{ }^{20,21}$ the outcome of this study. The questionnaire was applied by trained interviewers before the clinical examinations. The CPQ11-14 comprises 16 items regarding four domains: oral symptoms, functional limitations, emotional well-being, and social well-being. Each question has five possible answers in a Likert scale, scored from 0 to 4 . CPQ11-14 overall scores were calculated by adding the scores from each domain, and range from 0 to 64 . Higher overall scores denote that oral conditions have a greater negative impact on the child's quality of life.

\section{Contextual variables}

Contextual variables were obtained from official publications of Santa Maria, and they included the mean income of the neighborhood in which the school was located and the Basic School's Development Index (IDEB) of the school. 19,22 The IDEB index provides information about the school flow and the average performance of each student. It was implemented in 2007 by the Brazilian government to rank public schools according to the quality of education provided. The IDEB index combines the scholar flow and learning, expressing the progress of the education system in values from 0 to 10 . Averages are calculated from the data on the school approval obtained in the School Census and from performance in the Inep (National Institute of Studies and Educational Research) evaluations. ${ }^{22}$

\section{Data analysis}

Data analysis was performed using STATA 12 (Stata Corporation; College Station, USA). Descriptive statistics described the characteristics of the sample, as well as the averages of the CPQ11-14 domains and total scores.

Multilevel models were used to assess the association of individual and contextual factors with CPQ mean scores. The multilevel Poisson regression analysis considered fixed-effect models with random intercept, which allows demonstrating the fixed effects of association estimates between the outcome and the first and second level considering the adjustment by the variation in the intercept of the different contexts. The first model ("empty model") estimated the proportion of variance for each level before the incremental introduction of the individual and contextual independent variables. The second model ("individual model") included only the first-level variables. In the final model ("full model"), the associations were adjusted by the individual and 
contextual level covariates. In all models, the quality of fit was measured using deviance (-2log likelihood); statistically significant changes in the fitting of the models were assessed using the likelihood ratio.

\section{Results}

We evaluated 1,134 children, and the response rate was $93 \%$. The frequency of individual and contextual characteristics of the sample are summarized in Table 1. We observed that $54.1 \%$ of the individuals were girls and $77.9 \%$ of the parents classified their children's skin color as white. Moreover, $34.4 \%$ of mothers had not completed basic education and $85.6 \%$ of parents/ guardians reported practicing religious activities. Presence of untreated dental caries, malocclusion, and gingival bleeding was observed in 480 (42.2\%), 478 (42.3\%), and 298 (26.2\%) children, respectively. Regarding to the contextual variables, most children were enrolled in schools located in neighborhoods with a mean income $\leq 1,151.00$ Brazilian reals (minimum wage) and with $\geq 5.5$ grade in the IDEB. Overall and domain-specific CPQ11-14 scores according to the variables are also presented in Table 1. Children attending schools with lower IDEB scores presented higher scores in all CPQ11-14 domains.

The distribution of overall and domain-specific CPQ11-14 scores are presented in Table 2. The average CPQ11-14 score was 10.23 (SD 0.32). The variation observed was 0 to 43 , within the possible range of 0 to 64 .

The unadjusted association between individual and contextual variables with CPQ11-14 scores is presented in Table 3. All values were statistically significant, except for the variables "visits to the dentist in previous 6 months" (RR 0.98, 95\%CI 0.94-1.02) and "neighborhood's mean income" (rate ratio 0.94, 95\%CI 0.83-1.07).

The results of the multilevel adjusted analysis of the individual and contextual covariates for OHRQoL are shown in Table 4 . In model 1 (empty model), no variables were included. Individual variables were included in the Model 2, which presented statistically significant associations $(p<0.05)$. Children with untreated caries, malocclusion, and gingival bleeding presented higher CPQ11-14 mean scores than those without these conditions. In relation to household income, we observed a decreasing gradient in questionnaire average scores as the income categories increased. Furthermore, low mother's schooling, absence of religious practices, and not having visited the dentist in the previous 6 months were associated with a poor OHRQoL. The final model (full model or Model 3) included variables from the second level (contextual variables). The school's IDEB had an influence on the outcome. The mean CPQ11-14 score was 0.2 times lower for children enrolled in schools with an IDEB grade $\geq 5.5$ (rate ratio $0.80,95 \% \mathrm{CI} 0.74-0.88$ ) than for those who studied in schools with lower grades. The mean income of the school's neighborhood was not associated with OHRQoL.

\section{Discussion}

The present findings support the hypothesis that characteristics of the school environment may be related to poor OHRQoL in 12-year-old schoolchildren. Recent studies have consistently reported that poor oral conditions, psychosocial factors, and low socioeconomic status are related to the children's school performance and absenteeism..$^{23,24,25}$ However, the contextual effects of school environment on children's OHRQoL was not explored yet.

Individuals who studied in schools with lower IDEB scores, which combine the students' flow and school performance, presented higher mean CPQ11-14 scores. This association may have occurred due to the important role of the school in the individual intellectual and personal development. ${ }^{26}$ Possible explanations for our findings is that low OHRQoL may not be linked only to children's dental needs, but also with the place where they live, their interpersonal relationships, and the contextual factors that influence their life. These factors can lead to psychosocial decline, affecting their self-perception and self-image. ${ }^{26,27}$

Studies addressing the influence of school context in a child population are very important, once the longer the time people are exposed to environmental risks, the greater the likelihood of developing adverse health outcomes. ${ }^{28,29}$ Furthermore, these problems and their consequences affect not only childhood, but may 
Table 1. Descriptive distribution of overall and domain-specific CPQ11-14 scores according to individual and contextual level characteristics of the sample: 1,134 12-year-old children, Santa Maria - RS, Brazil.

\begin{tabular}{|c|c|c|c|c|c|c|}
\hline \multirow[t]{2}{*}{ Variables } & \multirow[t]{2}{*}{$\mathrm{n}(\%)^{*}$} & $C P Q_{11-14}$ total & Oral Symptoms & $\begin{array}{l}\text { Functional } \\
\text { limitation }\end{array}$ & $\begin{array}{l}\text { Emotional } \\
\text { well-being }\end{array}$ & $\begin{array}{c}\text { Social } \\
\text { well-being }\end{array}$ \\
\hline & & Mean $(\mathrm{SE})^{*}$ & Mean $(\mathrm{SE})^{*}$ & Mean $(\mathrm{SE})^{*}$ & Mean $(\mathrm{SE})^{*}$ & Mean (SE)* \\
\hline \multicolumn{7}{|l|}{ Individual level (child) } \\
\hline \multicolumn{7}{|l|}{ Gender } \\
\hline Male & $523(45.88)$ & $9.39(0.40)$ & $3.38(0.11)$ & $2.15(0.110)$ & $2.39(0.16)$ & $1.45(0.117)$ \\
\hline Female & $611(54.12)$ & $10.94(0.39)$ & $3.55(0.12)$ & $2.70(0.111)$ & $2.91(0.18)$ & $1.76(0.113)$ \\
\hline \multicolumn{7}{|l|}{ Skin color } \\
\hline White & 851 (77.93) & $9.92(0.34)$ & $3.47(0.09)$ & $2.40(0.07)$ & $2.51(0.17)$ & $1.53(0.09)$ \\
\hline Non-white & $245(22.07)$ & $11.46(0.49)$ & $3.53(0.18)$ & $2.66(0.14)$ & $3.31(0.19)$ & $1.94(0.16)$ \\
\hline \multicolumn{7}{|l|}{ Household income } \\
\hline Wealthy (3rd tertile) & $288(28.43)$ & $11.64(0.55)$ & $3.58(0.18)$ & $2.69(0.18)$ & $3.38(0.18)$ & $1.98(0.15)$ \\
\hline Intermediary ( $2^{\text {nd }}$ tertile) & $402(38.63)$ & $10.21(0.42)$ & $3.58(0.16)$ & $2.45(0.12)$ & $2.64(0.17)$ & $1.52(0.08)$ \\
\hline Poorest ( $1^{\text {st }}$ tertile) & $346(32.94)$ & $8.86(0.46)$ & $3.24(0.16)$ & $2.18(0.11)$ & $2.04(0.19)$ & $1.38(0.14)$ \\
\hline \multicolumn{7}{|l|}{ Mother's schooling } \\
\hline$>8$ years & $702(65.55)$ & $9.34(0.32)$ & $3.36(0.09)$ & $2.24(0.10)$ & $2.29(0.16)$ & $1.43(0.08)$ \\
\hline$<8$ years & $382(34.45)$ & $11.92(0.63)$ & $3.71(0.19)$ & $2.90(0.13)$ & $3.35(0.22)$ & $1.93(0.16)$ \\
\hline \multicolumn{7}{|l|}{ Practice of religious activities } \\
\hline Yes & $902(85.61)$ & $10.14(0.28)$ & $3.46(0.09)$ & $2.42(0.06)$ & $2.65(0.15)$ & $1.59(0.07)$ \\
\hline No & $158(14.39)$ & $11.15(0.86)$ & $3.77(0.24)$ & $2.69(0.19)$ & $2.84(0.28)$ & $1.83(0.28)$ \\
\hline \multicolumn{7}{|c|}{ Visits to dentist in previous 6 months } \\
\hline Yes & $514(47.43)$ & $10.14(0.38)$ & $3.55(0.13)$ & $2.51(0.09)$ & $2.46(0.18)$ & $1.62(0.13)$ \\
\hline No & $574(52.57)$ & $10.21(0.30)$ & $3.41(0.11)$ & $2.37(0.08)$ & $2.84(0.14)$ & $1.59(0.07)$ \\
\hline \multicolumn{7}{|l|}{ Untreated dental caries } \\
\hline Without & $654(57.72)$ & $9.62(0.32)$ & $3.38(0.09)$ & $2.29(0.08)$ & $2.39(0.16)$ & $1.55(0.10)$ \\
\hline With & $480(42.28)$ & $11.05(0.39)$ & $3.61(0.15)$ & $2.66(0.11)$ & $3.06(0.15)$ & $1.72(0.10)$ \\
\hline \multicolumn{7}{|l|}{ Malocclusion } \\
\hline Without & $656(57.64)$ & $9.57(0.27)$ & $3.41(0.09)$ & $2.35(0.092)$ & $2.41(0.14)$ & $1.38(0.07)$ \\
\hline With & $478(42.36)$ & $11.12(0.49)$ & $3.56(0.14)$ & $2.58(0.097)$ & $3.03(0.23)$ & $1.94(0.14)$ \\
\hline \multicolumn{7}{|l|}{ Gingival bleeding } \\
\hline Without & $836(73.76)$ & $9.83(0.31)$ & $3.36(0.08)$ & $2.39(0.06)$ & $2.52(0.16)$ & $1.55(0.08)$ \\
\hline With & $298(26.24)$ & $11.35(0.62)$ & $3.8(0.19)$ & $2.62(0.20)$ & $3.1(0.19)$ & $1.81(0.17)$ \\
\hline \multicolumn{7}{|l|}{ Contextual level (school) } \\
\hline \multicolumn{7}{|c|}{ Neighborhood's mean income } \\
\hline$>1151.00 \mathrm{BMW}^{* *}$ & $575(47.03)$ & $10.66(0.408)$ & $3.49(0.13)$ & $2.54(0.08)$ & $2.86(0.15)$ & $1.76(0.09)$ \\
\hline$\leq 1151.00 \mathrm{BMW}^{* *}$ & $559(52.97)$ & $9.84(0.404)$ & $3.46(0.12)$ & $2.37(0.11)$ & $2.5(0.21)$ & $1.5(0.11)$ \\
\hline \multicolumn{7}{|c|}{ Basic school's Development Index (IDEB) } \\
\hline$<5.5$ & $327(32.40)$ & $10.93(0.58)$ & $3.80(0.17)$ & $2.65(0.10)$ & $2.80(0.29)$ & $1.68(0.19)$ \\
\hline$\geq 5.5$ & $777(67.60)$ & $9.82(0.39)$ & $3.32(0.11)$ & $2.34(0.08)$ & $2.59(0.19)$ & $1.56(0.09)$ \\
\hline
\end{tabular}

*Prevalence, means and standard error (SE) were calculated taking into account the sampling weight; "BMW: Brazilian minimum wage (approximately US $\$ 450$ during the data gathering). 
School environment and individual factors influence oral health related quality of life in Brazilian children

Table 2. Descriptive distribution of overall and domain-specific CPQ11-14 scores.

\begin{tabular}{lcccc}
\hline Variable & Number of items & Averages scores CPQ1 1-14 (SE)* & Possible range & Observed range \\
\hline CPQ (overall scale) domains & 16 & $10.23(0.32)$ & $0-64$ & $0-43$ \\
Oral Symptoms & 4 & $3.48(0.09)$ & $0-20$ & $0-16$ \\
Functional Limitations & 4 & $2.45(0.07)$ & $0-20$ & $0-14$ \\
Emotional well-being & 4 & $2.68(0.15)$ & $0-20$ & $0-16$ \\
Social well-being & 4 & $1.62(0.08)$ & $0-20$ & $0-15$ \\
\hline
\end{tabular}

CPQ1 1-14: Child Perception Questionnaire; *Taking into account the sampling weight.

Table 3. Individual and contextual factors associated whit CPQ11-14 averages - Unadjusted Multilevel Analysis: 1,134 12-yearold children, Santa Maria - RS, Brazil.

\begin{tabular}{|c|c|c|}
\hline \multirow{2}{*}{ Variables } & $\mathrm{CPQ}_{11-14}$ Total & \multirow{2}{*}{$\operatorname{RR}(95 \% \mathrm{Cl})$} \\
\hline & Mean $(\mathrm{SE})^{*}$ & \\
\hline \multicolumn{3}{|c|}{ Individual level (child) } \\
\hline \multicolumn{3}{|l|}{ Gender } \\
\hline Male & $9.39(0.40)$ & $0.84(0.81-0.87)$ \\
\hline Female & $10.94(0.39)$ & 1 \\
\hline \multicolumn{3}{|l|}{ Skin color } \\
\hline Withe & $9.92(0.34)$ & 1 \\
\hline Non-white & $11.46(0.49)$ & $1.15(1.10-1.20)$ \\
\hline \multicolumn{3}{|l|}{ Household income } \\
\hline Wealthy (3rd tertile) & $8.86(0.46)$ & $0.78(0.74-0.83)$ \\
\hline Intermediary (2 $2^{\text {nd }}$ tertile $)$ & $9.39(0.35)$ & $0.90(0.86-0.94)$ \\
\hline Poorest ( $1^{\text {st }}$ tertile $)$ & $11.14(0.33)$ & 1 \\
\hline \multicolumn{3}{|l|}{ Mother's schooling } \\
\hline$>8$ years & $9.34(0.32)$ & 1 \\
\hline$<8$ years & $11.92(0.63)$ & $1.25(1.20-1.30)$ \\
\hline \multicolumn{3}{|l|}{ Practice of religious activities } \\
\hline Yes & $10.14(0.28)$ & 1 \\
\hline No & $11.15(0.86)$ & $1.08(1.03-1.14)$ \\
\hline \multicolumn{3}{|c|}{ Visits to dentist in previous 6 months } \\
\hline Yes & $10.14(0.38)$ & 1 \\
\hline No & $10.21(0.30)$ & $0.98(0.94-1.02)$ \\
\hline \multicolumn{3}{|l|}{ Untreated dental caries } \\
\hline Without & $9.62(0.32)$ & 1 \\
\hline With & $11.05(0.39)$ & $1.10(1.06-1.14)$ \\
\hline \multicolumn{3}{|l|}{ Malocclusion } \\
\hline Without & $9.57(0.27)$ & 1 \\
\hline With & $11.12(0.49)$ & $1.15(1.11-1.19)$ \\
\hline \multicolumn{3}{|l|}{ Gingival bleeding } \\
\hline Without & $9.83(0.31)$ & 1 \\
\hline With & $11.35(0.62)$ & $1.17(1.12-1.22)$ \\
\hline \multicolumn{3}{|c|}{ Contextual level (school) } \\
\hline \multicolumn{3}{|c|}{ Neighborhood's mean income } \\
\hline$>1151.00 \mathrm{BMW}^{\dagger}$ & $10.66(0.408)$ & 1 \\
\hline$\leq \mathrm{R} \$ 1151.00 \mathrm{BMW}^{+}$ & $9.84(0.404)$ & $0.94(0.83-1.07)$ \\
\hline \multicolumn{3}{|c|}{ Basic School's Development Index (IDEB) } \\
\hline$<5.5$ & $10.93(0.58)$ & 1 \\
\hline
\end{tabular}

*Means and standard error (SE) were calculated taking into account the sampling weight; ${ }^{* * B M W: ~ B r a z i l i a n ~ m i n i m u m ~ w a g e ~(a p p r o x i m a t e l y ~}$ US $\$ 450$ during the data gathering). 
Table 4. Individual and contextual factors associated whit CPQ1 1 - 14 averages - Adjusted multilevel analysis poisson regression: 1,134 12-year-old children, Santa Maria - RS, Brazil.

\begin{tabular}{|c|c|c|c|}
\hline Variable & Model 1 ("empty") & Model 2 ("individual") & Model 3 ("full") \\
\hline Fixed component & $\operatorname{RR}(95 \% \mathrm{Cl})$ & $\operatorname{RR}(95 \% \mathrm{Cl})$ & $\operatorname{RR}(95 \% \mathrm{Cl})$ \\
\hline Intercept & $10.23(9.59-10.92)$ & $9.75(8.95-10.62)$ & $6.03(3.70-9.82)$ \\
\hline \multicolumn{4}{|c|}{ Individual level (child) } \\
\hline \multicolumn{4}{|l|}{ Gender } \\
\hline Male & & $0.82(0.79-0.86)^{*}$ & $0.84(0.81-0.88)^{*}$ \\
\hline Female & & 1 & 1 \\
\hline \multicolumn{4}{|l|}{ Skin color } \\
\hline White & & 1 & 1 \\
\hline Not white & & $1.05(1.00-1.10)^{* *}$ & $1.05(0.99-1.10)^{* *}$ \\
\hline \multicolumn{4}{|l|}{ Household income } \\
\hline Wealthy ( $3^{\text {rd }}$ tertile) & & $0.84(0.79-0.89)^{*}$ & $0.84(0.79-0.89)^{*}$ \\
\hline Intermediary (2nd tertile) & & $0.92(0.87-0.96)^{*}$ & $0.93(0.88-0.97)^{*}$ \\
\hline Poorest ( $1^{\text {st }}$ tertile $)$ & & 1 & 1 \\
\hline \multicolumn{4}{|l|}{ Mother's schooling } \\
\hline$>8$ years & & 1 & 1 \\
\hline$<8$ years & & $1.16(1.10-1.21)^{*}$ & $1.15(1.10-1.20)^{*}$ \\
\hline \multicolumn{4}{|l|}{ Practice of religious activities } \\
\hline Yes & & 1 & 1 \\
\hline No & & $1.09(1.03-1.15)^{*}$ & $1.14(1.07-1.21)^{*}$ \\
\hline \multicolumn{4}{|c|}{ Visits to dentist in previous 6 months } \\
\hline Yes & & 1 & 1 \\
\hline No & & $0.95(0.91-0.99)^{* *}$ & $0.95(0.91-0.99)^{* *}$ \\
\hline \multicolumn{4}{|l|}{ Untreated dental caries } \\
\hline Without & & 1 & 1 \\
\hline With & & $1.09(1.04-1.14)^{*}$ & $1.11(1.06-1.15)^{*}$ \\
\hline \multicolumn{4}{|l|}{ Malocclusion } \\
\hline Without & & 1 & 1 \\
\hline With & & $1.13(1.09-1.18)^{*}$ & $1.12(1.07-1.17)^{*}$ \\
\hline \multicolumn{4}{|l|}{ Gingival bleeding } \\
\hline Without & & 1 & 1 \\
\hline With & & $1.16(1.11-1.21)^{*}$ & $1.15(1.10-1.20)^{*}$ \\
\hline \multicolumn{4}{|c|}{ Contextual level (school) } \\
\hline \multicolumn{4}{|l|}{ Neighborhood's mean income } \\
\hline$>1151.00 \mathrm{BMW}^{+}$ & & & 1 \\
\hline$\leq 1151.00 \mathrm{BMW}^{\dagger}$ & & & $0.99(0.91-1.07)^{* *}$ \\
\hline \multicolumn{4}{|c|}{ Basic school's Development Index (IDEB) } \\
\hline$<5.5$ & & & 1 \\
\hline$\geq 5.5$ & & & $0.80(0.74-0.88)^{*}$ \\
\hline \multicolumn{4}{|l|}{ Random component } \\
\hline Deviance (-2loglikelihood) & 10361.45 & 80.373 .124 & 7.782 .501 \\
\hline
\end{tabular}

Model 1 ("empty") was an unconditional model; Model 2 was the model adjusted for individual level variables; Model 3 was adjusted for individual and contextual level variables. ${ }^{*} p<0.00 ;{ }^{* *} p<0.05 ;{ }^{* * *} B M W$ : Brazilian minimum wage (approximately US $\$ 450$ during the data gathering). 
persist throughout life..$^{29}$ A systematic review showed that home environment characteristics, such as family structure, household crowding, and presence of siblings were significant predictors of children's OHRQoL. ${ }^{11}$ As with family, school is where people are educated, thus, improving these institutions generates benefits in all aspects of children's lives and creates better future perspectives. ${ }^{26} \mathrm{~A}$ recent study conducted with Brazilian adolescents and young adults found that poor school environmental, including lack of security and bullying, were associated with poor OHRQoL. ${ }^{27}$ Therefore, contextual evaluations suggest that family and school environments are related to OHRQoL.11,12,27

Similar to our findings, previous studies have shown evidence of negative impact of untreated caries, ${ }^{30,31}$ gingival bleeding, ${ }^{5,32}$ and malocclusion ${ }^{33,34}$ on OHRQoL. It has also been demonstrated that socioeconomic level, like low income and low maternal education, resulted in poorer oral health and OHRQoL. ${ }^{3,4,35,36}$ Socioeconomic barriers are associated with a decreased searching of services, and the combination of perceived need for treatment and absence of resources for searching health professionals can generate discontent and discomfort. ${ }^{37,38}$

The cross-sectional nature of the data limits the temporal relationship between the investigated predictors and OHRQoL. However, cross-sectional studies are important tools for identifying risk and protection indicators for inclusion in future

\section{References}

1. Glick M, Williams DM, Kleinman DV, Vujicic M, Watt RG, Weyant RJ. A new definition for oral health developed by the FDI World Dental Federation opens the door to a universal definition of oral health. Int Dent J. 2016 Dec;66(6):322-4. https://doi.org/10.1111/idj.12294

2. Sischo L, Broder HL. Oral health-related quality of life: what, why, how, and future implications. J Dent Res. 2011 Nov;90(11):1264-70. https://doi.org/10.1177/0022034511399918

3. Scarpelli AC, Paiva SM, Viegas CM, Carvalho AC, Ferreira FM, Pordeus IA. Oral health-related quality of life among Brazilian preschool children. Community Dent Oral Epidemiol. 2013 Aug;41(4):336-44. https://doi.org/10.1111/cdoe.12022 longitudinal assessments. We were unable to include students who were enrolled in private schools. Nevertheless, $85 \%$ of the city's children in this age group were enrolled in public schools in Santa Maria. Moreover, chi-squared tests were conducted to compare our sample with the city's population, and no difference was observed for gender, race, and household income (data provided by the Demographic Council of the City). Therefore, we cautiously consider the generalization of findings for all 12-year-old schoolchildren living in Santa Maria.

\section{Conclusion}

In conclusion, our findings indicated that clinical and socioeconomic factors and school environment are associated with OHRQoL among schoolchildren. This knowledge is important for reducing inequalities in educational quality and planning public health policies to improve the health and well-being of schoolchildren.

\section{Acknowledgments}

The authors wish to thank all children, parents, and schools for their participation and collaboration in this study and the Municipal Education Authorities of Santa Maria, RS, for their information and authorization to conduct the research. The authors declare that they have no conflicts of interest.
4. de Paula JS, Leite IC, Almeida AB, Ambrosano GM, Mialhe $\mathrm{FL}$. The impact of socioenvironmental characteristics on domains of oral health-related quality of life in Brazilian schoolchildren. BMC Oral Health. 2013 Jan;13:10. https://doi.org/10.1186/1472-6831-13-10

5. Tomazoni F, Zanatta FB, Tuchtenhagen S, Rosa GN, Del Fabro JP, Ardenghi TM. Association of gingivitis with child oral healthrelated quality of life. J Periodontol. 2014 Nov;85(11):1557-65. http://doi.org/10.1902/jop.2014.140026

6. Rosa GN, Del Fabro JP, Tomazoni F, Tuchtenhagen S, Alves LS, Ardenghi TM. Association of malocclusion, happiness, and oral health-related quality of life (OHRQoL) in schoolchildren. J Public Health Dent. 2016 Mar;76(2):85-90. https://doi.org/10.1111/iphd.12111 
7. Schuch HS, Costa FS, Torriani DD, Demarco FF, Goettems ML. Oral health-related quality of life of schoolchildren: impact of clinical and psychosocial variables. Int J Paediatr Dent. 2015 Sep;25(5):358-65. https://doi.org/10.1111/ipd.12118

8. Guedes RS, Piovesan C, Antunes JL, Mendes FM, Ardenghi TM. Assessing individual and neighborhood social factors in child oral health-related quality of life: a multilevel analysis. Qual Life Res. 2014 Nov;23(9):2521-30. https://doi.org/10.1007/s11136-014-0690-z

9. Vettore MV, Aqeeli A. The roles of contextual and individual social determinants of oral health-related quality of life in Brazilian adults. Qual Life Res. 2016 Apr;25(4):1029-42. https://doi.org/10.1007/s11136-015-1118-0

10. Aida J, Ando Y, Oosaka M, Niimi K, Morita M. Contributions of social context to inequality in dental caries: a multilevel analysis of Japanese 3-year-old children. Community Dent Oral Epidemiol. 2008 Apr;36(2):149-56. https://doi.org/10.1111/j.1600-0528.2007.00380.x

11. Kumar S, Kroon J, Lalloo R. A systematic review of the impact of parental socio-economic status and home environment characteristics on children's oral health related quality of life. Health Qual Life Outcomes. 2014 Mar;12(1):41. https://doi.org/10.1186/1477-7525-12-41

12. Alves FN, de Andrade CL, Vettore MV. Planning oral health care using the sociodental approach and the index of family living conditions: a cross-sectional study in Brazilian adolescents. BMC Res Notes. 2015 Oct;8(1):588. https://doi.org/10.1186/s13104-015-1564-3

13. Alsumait A, EISalhy M, Raine K, Cor K, Gokiert R, AlMutawa S, Amin M. Impact of dental health on children's oral health-related quality of life: a cross-sectional study. Health Qual Life Outcomes. 2015 Jul;13:98. https://doi.org/10.1186/s12955-015-0283-8

14. World Healt Organization - WHO. Continuous improvement of oral health in the 21st century: the approach of the WHO Global Oral Health Programme. Geneva: World Healt Organization; 2003.

15. World Healt Organization - WHO. Oral health surveys, basic methods. Geneva: World Health Organization; 1997.

16. Jenny J, Cons NC. Establishing malocclusion severity levels on the Dental Aesthetic Index (DAI) scale. Aust Dent J. 1996 Feb;41(1):43-6. https://doi.org/10.1111/j.1834-7819.1996.tb05654.x

17. American Dental Association - ADA. Acceptance program guidelines toothbrushes. Chicago: American Dental Association; 1998.

18. Instituto Brasileiro de Geografia e Estatística - IBGE. Síntese de indicadores sociais: uma análise das condições de vida da populaçãoo brasileira. Rio de Janeiro: Instituto Brasileiro de Geografia e Estatística; 2010.

19. Instituto Brasileiro de Geografia e Estatística - IBGE. Resultados da amostra: trabalho e rendimento. Rio de Janeiro: Instituto Brasileiro de Geografia e Estatística; 2010 [cited 2013 May 22]. Available from: http://www.sidra.ibge.gov.br
20. Jokovic A, Locker D, Stephens M, Kenny D, Tompson B, Guyatt G. Validity and reliability of a questionnaire for measuring child oral-health-related quality of life. J Dent Res. 2002 Jul;81(7):459-63. https://doi.org/10.1177/154405910208100705

21. Goursand D, Paiva SM, Zarzar PM, Ramos-Jorge ML, Cornacchia GM, Pordeus IA et al. Cross-cultural adaptation of the Child Perceptions Questionnaire 11 14 (CPQ1 1-14) for the Brazilian Portuguese language. Health Qual Life Outcomes. 2008 Jan;6(1):2. https://doi.org/10.1186/1477-7525-6-2

22. Instituto Nacional de Estudos e Pesquisas Educacionais Anísio Teixeira - INEP. Portal Ideb. 2013 [cited 2015 Out 22]. Available from: http://portal.inep.gov.br/web/portal-ideb/portal-ideb

23. Blumenshine SL, Vann WF Jr, Gizlice Z, Lee JY. Children's school performance: impact of general and oral health. J Public Health Dent. 2008 Spring;68(2):82-7. https://doi.org/10.1111/i.1752-7325.2007.00062.x

24. Piovesan C, Antunes JL, Mendes FM, Guedes RS, Ardenghi TM. Influence of children's oral health-related quality of life on school performance and school absenteeism. J Public Health Dent. 2012 Spring;72(2):156-63. https://doi.org/10.1111/j.1752-7325.2011.00301.x

25. Seirawan H1, Faust S, Mulligan R. The impact of oral health on the academic performance of disadvantaged children. Am J Public Health. 2012 Sep;102(9):1729-34. https://doi.org/10.2105/AJPH.2011.300478

26. Silva SGO. A escola na formação do cidadão. Artigonal. com. [cited 2015 Out 22]. Available from: http://www. artigonal.com/ciencia-artigos/a-escola-na-formacao-docidadao481121.html

27. Alwadi MA, Vettore MV. Are school and home environmental characteristics associated with oral health-related quality of life in Brazilian adolescents and young adults? Community Dent Oral Epidemiol. 2017 Aug;45(4):356-64. https://doi.org/10.1111/cdoe.12298

28. Kalff AC, Kroes M, Vles JS, Hendriksen JG, Feron FJ, Steyaert J et al. Neighbourhood level and individual level SES effects on child problem behaviour: a multilevel analysis. J Epidemiol Community Health. 2001 Apr;55(4):246-50. https://doi.org/10.1136/jech.55.4.246

29. Holst D, Schuller AA. Oral health in a life-course: birth-cohorts from 1929 to 2006 in Norway. Community Dent Health. 2012 Jun;29(2):134-43. https://doi.org/10.1922/CDH 2780Holst10

30. Piovesan C, Antunes JL, Guedes RS, Ardenghi TM. Impact of socioeconomic and clinical factors on child oral health-related quality of life (COHRQoL). Qual Life Res. 2010 Nov; 19(9):135966. https://doi.org/10.1007/s11136-010-9692-7

31. Abanto J, Carvalho TS, Mendes FM, Wanderley MT, Bönecker $M$, Raggio DP. Impact of oral diseases and disorders on oral health-related quality of life of preschool children. Community Dent Oral Epidemiol. 2011 Apr;39(2):105-14. https://doi.org/10.1111/j.1600-0528.2010.00580.x 
32. Foster Page LA, Thomson WM, Jokovic A, Locker D. Validation of the Child Perceptions Questionnaire (CPQ 11-14). J Dent Res. 2005 Jul;84(7):649-52. https://doi.org/10.1177/154405910508400713

33. Ukra A, Foster Page LA, Thomson WM, Farella M, Tawse Smith A, Beck V. Impact of malocclusion on quality of life among New Zealand adolescents. N Z Dent J. 2013 Mar;109(1):18-23.

34. Scapini A, Feldens CA, Ardenghi TM, Kramer PF. Malocclusion impacts adolescents' oral health-related quality of life. Angle Orthod. 2013 May;83(3):512-8. https://doi.org/10.2319/062012-509.1

35. Pine CM, Adair PM, Nicoll AD, Burnside G, Petersen PE, Beighton $D$ et al. International comparisons of health inequalities in childhood dental caries. Community Dent Health. 2004 Mar;21(1 Suppl):121-30.
36. Traebert J, Guimarães LA, Durante EZ, Serratine AC. Low maternal schooling and severity of dental caries in Brazilian preschool children. Oral Health Prev Dent. 2009;7(1):39-45.

37. Machry RV, Tuchtenhagen S, Agostini BA, Teixeira CRS, Piovesan C, Mendes FM et al. Socioeconomic and psychosocial predictors of dental healthcare use among Brazilian preschool children. BMC Oral Health. 2013 Oct;13(1):60. https://doi.org/10.1186/1472-6831-13-60

38. Gomes MC, Clementino MA, Pinto-Sarmento TC, Costa EM, Martins CC, Granville-Garcia AF et al. Parental perceptions of oral health status in preschool children and associated factors. Braz Dent J. 2015 Jul Aug;26(4):428-34. https://doi.org/10.1590/0103-6440201300245 